\title{
Associations of Income and Wealth with Health Status in the Korean Elderly
}

\author{
Bo-Hyun Park, Minsoo Jung, Tae-Jin Lee \\ Department of Health Policy and Management, Seoul National University School of Public Health
}

Objectives : This study aimed to verify the association between wealth or income level and health status after adjusting for other socio-economic position (SEP) indicators among Korean adults aged 45 and over.

Methods : Data were obtained from the 1st wave of Korean Longitudinal Study of Ageing (households: 6,171, persons: 10,254). We used self-rated health status and activities of daily living (ADLs) as dependent variables. Explanatory variables included both net wealth measured by savings, immovables, the other valuated assets and total income including pay, transfer, property and so on. Binary logistic regression was conducted to examine the relationships. Also, in order to determine the relative health inequality across economic groups, we estimated the relative index of inequality (RII).

Results : The inequality of health status was evident among various wealth and income groups. The wealthiest group (5th quintile) was much healthier than the poorest group, and this differential increased with age. Likewise, higher income was associated with better health status among the elderly. However, these effects, as measured by the odds ratio and RII, showed that wealth was more important in determining health status of elderly people.

Conclusions : This study suggests that economic capability plays a significant role in determining the health status and other health-related problems among the elderly. Particularly, our results show that health status of the aged is related more closely to the individual's wealth than income.

J Prev Med Public Health 2009;42(5):275-282

$\overline{\text { Key words }}$ : Socioeconomic position, Wealth, Income, Elderly, Health inequality

\section{INTRODUCTION}

Much evidence indicates that social status is related to the factors that determine one's health [1-5]. Of course, social determining factors do not affect health problems directly, not like diseases do [1,6]. Nevertheless, researches concerning each socio-economic position (SEP) index widely show that these are related to overall health status and life expectancy [7-9]. Especially, economic condition is one of the most important variables of SEP. The problem is that economic condition varies according to age. Supposing that income and wealth are two main categories of economic condition, the health status gap between senior (age 45 to 64 ) and elderly (age 65 or above) groups makes the variation of economic condition more possible. Income and wealth are SEP indexes which measure economic situation directly [10,11]. Of course the 'income effect,' which affects health, is valid as far as it is consumed or converted to promote a more pleasant living environment. Labor conditions, the living environment, adequate physical activity, good food and other healthy managements are these income effects. Thus, the income should be rechecked in the aspect of consuming behavior.

Higher income alone does not result in better health status, but, rather, other SEP indicators which interact with higher income and other individual situations should be considered. Since income is an indicator relatively measured in the short term, the cumulative effect of income toward one's health is unlikely to be shown without regarding its dynamic aspects in one's lifetime. Thus, there needs to be a close examination when utilizing the income variable [12].

Income is mostly measured as household income rather than individual income. Though the error range is low in the individual income, the household income is useful for this research because the individual income is usually distributed and possessed by family members. Thus, the number of family members, the number of family members with a stable income and their sex, the number and ages of the family members without labor power and the relationship between the provider and the dependent family should be standardized [13]. And for a given period of time, income increases according to age and is influenced by one's employment history. Especially, the income deviation and comparability due to diversity of fringe benefit and wage system by occupation need to be checked. In short, as the direct evaluation scale for economic condition, income is an indicator to grasp the degree of utilization of technique and labor. But it should be analyzed considering the wealth variable based on its fluctuation degree and age effect.

Wealth is not only the accumulation of 
income, but is also a factor that consists of various types of assets, such as houses, automobiles, investments, inheritances and family affluence scale (FAS) [14]. In the aspect of public health this accumulation of financial resources is a more significant variable than income to estimate one's health status $[1,3,6]$. However, when regarding both income and wealth, which may have some reverse relations, it should be approached with care by using the life course approach. Thus, it is necessary to check whether retired people who have low income but much wealth and colored races who have relatively less wealth were targeted. Furthermore, unlike pay income, which is measured while one is working in relation to one's occupation, wealth is a complex factor. Thus, it reflects a relatively long and stable individual market capacity in spite of the changes in the social and political environments. Then market capacity is a concept which includes one's buying power and potential accessibility to resources. While income depends on individual achievements in the labor market, wealth includes finance and immovable property formed by inheritance and transference, not to mention income.

All domestic researches on SEP and perceived health status (PHS) of seniors and the elderly show that one's low socioeconomic status inevitably leads to one's poor health status $[15,16]$. The lower one's socioeconomic status, the poorer one's health status [17]. Income is an indicator which is able to be compared equally in all age groups, so it is adopted in researches broadly. However, in some researches on the elderly, there is a limitation to explaining their economic status by measuring only their income. In the case of the elderly, most of them are retired from actual work so their incomes tend to be temporary. Thus, the income of an elderly person cannot be the proper indicator to measure his or her economic status [18]. It is reported that not only income but also wealth has a strong relationship with health [19]. Wealth is significant as it is an accumulative effect of the economic status acquired through one's lifetime. However, the existing researches haven't paid much attention to telling them apart in spite of previous problems. Thus, this research aimed to investigate how the effect of income and wealth varies depending on sex and age (dividing groups into those over 65 and those under 65), with a domestic group of seniors and the elderly as the targets.

\section{METHODS AND MATERIALS}

\section{Subjects}

The research material is Korea Labor Institute's Korean Longitudinal Study of the Aging (KLoSA) dataset. This survey aims to grasp whether seniors and the elderly participate in the labor market, their income and wealth levels, the effect of Social Security on them, their health status, and income transference within families. The survey objects are Korean citizens dwelling nationwide who are not less than 45 years old. In the first round survey, interview surveys on 10,254 persons from 6,171 households of 999 primary sampling units were carried out. The 2006 survey which was used in this research utilized computer assisted personal interviewing (CAPI), which required the use of a laptop computer. When the sample size is bigger and has a more complex question structure than paper and pencil interviewing, CAPI guarantees the reliability of the survey results. The survey item consists of eight categories: population, family, health, employment, income, wealth, subjective expectancy, and quality of life. This research combined the personal data of the elderly and the household data, and analyzed them. In addition, as this survey is a national sample survey, the weight which considers the sampling rate and the response rate was applied.

\section{Variables}

\section{A. Independent variables}

Wealth and income variables were considered as the main SEP index in this research. In the aspect that wealth and income both determine one's economic status, they have considerable correlation, and this can cause a multicollinearity problem. Former researches indicate that the correlation between income and wealth is $\mathrm{r}=0.05-0.29$ [20,21], while this research shows $r=0.39$. Since variance inflation factor (VIF) of income and wealth variables appeared in a ratio of 1.42 to 3.11 in each model, the problem of multicollinearity is unlikely to occur even if two variables are put simultaneously.

The composition of the wealth and income variables was calculated using the method shown in Tables 1 and 2. The net wealth, which measures one's total assets (real estate assets, financial assets, and other assets) exclusive of one's total debts (bank loan, home mortgage [to be repaid someday], and others) was the base for wealth. Total income, which is the sum of pay income, transfer income, wealth income, and others for the year 2006 was the base for income. This method is a usual calculation method used in researches on household wealth [22-27]. By this method, net wealth and total income are calculated individually and added up conjugally, so that each husband and wife of one couple have the same value. Each couple's (a total of 6,763 couples) net wealth and total income were divided into quintiles (1st is the lowest and 5th is th highest). Then each couple's value of quintile on the wealth and income was equally given to individual persons. This is because any person's income is usually benefit all the members of one's family. Generally, when the income status is measured, the household income is used, but in this research the income and wealth of an elderly couple was used. In researches on the elderly, the measured value per each household means a proxy variable which is used on the premise that a household's 
Table 1. A detailed statement of wealth structure

\begin{tabular}{|c|c|}
\hline Items & Contents \\
\hline Total assets & $\begin{array}{l}\text { Total savings + The evaluated value of real estate based on the current prices }+ \text { The } \\
\text { evaluated value of other assets }\end{array}$ \\
\hline Net assets & Total assets - Total debt \\
\hline Financial assets & Savings + Deposit money of rent house + Deposit money of monthly rent house \\
\hline Savings & $\begin{array}{l}\text { Accumulative investment }+ \text { Round sum investment }+ \text { Others (Lodge money paid }+ \\
\text { loan money) }\end{array}$ \\
\hline Deposit money of rent house & The money paid for rent house, to be returned someday \\
\hline Total debts & Amount of debts + Deposit money of lease house \\
\hline Amount of debts & $\begin{array}{l}\text { Bank loan + Others (Loaned money from individuals/loaning company/one's } \\
\text { holding office + Lodge money due) }\end{array}$ \\
\hline Deposit money of lease house & The money paid for lease house, to be repaid someday \\
\hline Real estate assets & House + The others except house \\
\hline House & Present dwelling house + The others except present dwelling house \\
\hline The others except house & Land + Building + Fully or partially paid money for a lot-solid apartment \\
\hline The other assets & $\begin{array}{l}\text { Automobile + The other non-financial assets (Golf and condominium membership, } \\
\text { precious metals, antique, work of arts, expensive durable goods) }\end{array}$ \\
\hline
\end{tabular}

Table 2. A detailed statement of income structure

\begin{tabular}{ll}
\hline \multicolumn{1}{c}{ Items } & \multicolumn{1}{c}{ Contents } \\
\hline Total income & $\begin{array}{c}\text { Pay income + Transfer income + Assets income + Others } \\
\text { Pay income + Self-employed income + Agriculture and fishery income + Side job } \\
\text { income }\end{array}$ \\
Transfer income & Public transfer income + Private transfer income \\
Public transfer income & Public pension income + Social security income \\
Public pension income & National pension income +Special occupation pension income \\
Social security income & Unemployment allowance income + Industrial disaster allowance income + \\
& Allowance income by national basic livelihood security program + National \\
Private transfer income & patriot annuity income + The other social welfare allowance income \\
Total financial support received - Total financial support (Sons and daughters, & parents, and the other family) \\
Assets income & Financial assets income + Real estate income \\
The others & Personal pension income + The other income and earnings \\
\hline
\end{tabular}

income will be distributed equally to all family members. However, a directly measured value on the income and wealth of the elderly was available in this dataset, so it was used in this research.

\section{B. Dependent variables}

The dependent variables are PHS and activities of daily living (ADL), representing one's health status. PHS consists of a 5-scale item of "very good," "good," "average," "bad," and "very bad"; however, for analysis, a binary value system was adopted: "bad" and "very bad" are considered as 1, and "very good," "good," and "usual" are considered as 0 . ADL is a variable which represents one's health status more objective than PHS. 7 ADLs (changing one's clothes, washing one's face/brushing one's teeth/shampooing one's hair, taking a bath/taking a shower, eating a breakfast that has been prepared for them, getting up and getting out of the bedroom, using the bathroom, not letting one's feces and residence (metropolitan city, medium and small city, town) were selected as control variables.

\section{Statistical Analysis}

All analyses were sorted into two groups by sex and age and then carried out to control the interaction effect of sex and age. The age group was divided into two groups: middle age $(45 \leq$ $x<65)$ and old age $(65 \leq x)$. This was done in order to distinguish the different kinds of influence that income and wealth have on the elderly and the non-elderly. First, the descriptive statistics were used for analysis: the frequency and percentage of each variable were checked. Second, wealth and income were divided into quintiles and their influence on PHS and ADL was analyzed by binary logistic regression. The result was presented as odds ratio (OR) and 95\% confidence interval (CI). In all analyses, one's education level, type of household, the existence or nonexistence of a mate, and place of residence were controlled.

To check whether an inequality of health according to wealth and income status exists, the relative index of inequality (RII) was calculated. RII is an indicator which reflects the change in the degree of inequality into a numerical value considering the spread of a population according to each SEP. Recently, it is being more frequently used in health inequality research. Since the income and wealth variables used in this research are divided into quintiles, it can be regarded as an ordinal variable. In this case, RII can be used as an indicator which shows a relative gap between the highest group and the lowest group. Especially, RII is useful because it can reflect the differences among a population structure [28]. Furthermore, RII, by single index, briefly presents the difference of dependent variables according to the relative position of income and wealth status. As the dependent variable is a binary value, RII's statistical significance was tested after the degree of relative inequality to income and 
wealth was checked by logistic regression. As the lowest ranking group was put as the first group, when RII is smaller than 1 , the inequality is disadvantageous to the person who has a higher level of wealth and income; when RII is bigger than 1 , the inequality is disadvantageous to the person who has a lower level of wealth and income $[29,30]$.

\section{RESULTS}

\section{Socio-demographic Characteristics of the Sample}

The average age among the research objects were 61.2 (male) and 62.1 (female) and the proportion of those over the age of 65 was $38.9 \%$ (male) and $41.8 \%$ (female). Overall, the rate of "not good" was higher for those over the age of 65 than for those under the age of 65 This was also the case for women rather than men and for seniors and the elderly, in the aspect of sex. The rate of "have a disability" was higher for those over the age of 65 than for those under the age of 65 , results similar to those of the PHS. In the aspect of sex, the rate of "have a disability" was shown to be higher in men than in women when the age is under 65 , but higher in women when the age is not less than 65 . And then in the case of wealth and income in the SEP index, the wealth and income level tends to be lower when the age is not less than 65 than when it is under 65 . In the case of sex, women's wealth and income level tends to be lower than that of men. In the case of academic background, the proportion of those who are at least a high school graduate is $33 \%$ when it comes to men who are not less than 65 years old; however it is $7 \%$ when it comes to women who are not less than 65 years old.

What is especially noteworthy of these demographic features is that men who are married and who are not less than 65 years old have, by a remarkable contrast, a superior academic background over women who are married and are not less than 65 years old $(90 \%$ to $43 \%$ ); and in the case of family type women
Table 3. General characteristics by demographic and socioeconomic indicators in different age groups

\begin{tabular}{|c|c|c|c|c|c|c|c|c|}
\hline \multirow{3}{*}{ Variables } & \multicolumn{4}{|c|}{ Male } & \multicolumn{4}{|c|}{ Female } \\
\hline & \multicolumn{2}{|c|}{$45-64$} & \multicolumn{2}{|c|}{$\geq 65$} & \multicolumn{2}{|c|}{$45-64$} & \multicolumn{2}{|c|}{$\geq 65$} \\
\hline & $\mathrm{n}$ & $\%$ & $\mathrm{n}$ & $\%$ & $\mathrm{n}$ & $\%$ & $\mathrm{n}$ & $\%$ \\
\hline \multicolumn{9}{|l|}{ Health status } \\
\hline \multicolumn{9}{|l|}{ Self-rated health } \\
\hline Poor & 409 & 15.0 & 636 & 36.6 & 783 & 23.2 & 1,359 & 56.2 \\
\hline No poor & 2,321 & 85.0 & 1,100 & 53.5 & 2,586 & 76.8 & 1,060 & 43.8 \\
\hline \multicolumn{9}{|c|}{ Limitation of activities of daily living } \\
\hline Disability & 322 & 11.8 & 424 & 24.4 & 141 & 4.2 & 629 & 26.0 \\
\hline No disability & 2,408 & 88.2 & 1,312 & 75.6 & 3,228 & 95.8 & 1,790 & 74.0 \\
\hline \multicolumn{9}{|l|}{ Socioeconomic position } \\
\hline \multicolumn{9}{|c|}{ Net wealth group (quintile) } \\
\hline $1 \mathrm{st}(\leq 20 \%)$ & 292 & 10.7 & 262 & 15.1 & 443 & 13.1 & 779 & 32.2 \\
\hline 2nd $(21-40 \%)$ & 358 & 13.1 & 282 & 16.2 & 501 & 14.9 & 532 & 22.0 \\
\hline $3 \operatorname{rd}(41-60 \%)$ & 519 & 19.0 & 449 & 25.9 & 706 & 21.0 & 507 & 21.0 \\
\hline 4th $(61-80 \%)$ & 723 & 26.5 & 391 & 22.5 & 827 & 24.6 & 337 & 13.9 \\
\hline 5 th $(81-100 \%)$ & 838 & 30.7 & 352 & 20.3 & 892 & 26.5 & 264 & 10.9 \\
\hline \multicolumn{9}{|c|}{ Total income group (quintile) } \\
\hline $1 \mathrm{st}(\leq 20 \%)$ & 323 & 11.8 & 226 & 13.0 & 530 & 15.7 & 574 & 23.7 \\
\hline 2nd $(21-40 \%)$ & 192 & 7.0 & 414 & 23.9 & 417 & 12.4 & 887 & 36.7 \\
\hline $3 \operatorname{rd}(41-60 \%)$ & 322 & 11.8 & 478 & 27.5 & 568 & 16.9 & 520 & 21.5 \\
\hline 4th $(61-80 \%)$ & 850 & 31.1 & 370 & 21.3 & 872 & 25.9 & 270 & 11.2 \\
\hline 5th $(81-100 \%)$ & 1,043 & 38.2 & 248 & 14.3 & 982 & 29.2 & 168 & 7.0 \\
\hline \multicolumn{9}{|l|}{ Education ${ }^{*}$} \\
\hline$\leq$ Elementary & 505 & 18.5 & 919 & 53.0 & 1,299 & 38.6 & 2,101 & 86.9 \\
\hline Middle & 510 & 18.7 & 249 & 14.4 & 739 & 22.0 & 159 & 6.6 \\
\hline High & 1,127 & 41.3 & 373 & 21.5 & 1,079 & 32.1 & 129 & 5.3 \\
\hline$\geq$ College & 586 & 21.5 & 194 & 11.2 & 249 & 7.4 & 28 & 1.2 \\
\hline \multicolumn{9}{|c|}{ Demographic characteristics } \\
\hline \multicolumn{9}{|l|}{ Marital status } \\
\hline Married & 2,533 & 92.8 & 1,557 & 89.7 & 2,839 & 84.3 & 1,042 & 43.1 \\
\hline No partner & 197 & 7.2 & 179 & 10.3 & 530 & 15.7 & 1,377 & 57.0 \\
\hline \multicolumn{9}{|l|}{ Housing type } \\
\hline Own house & 2,105 & 77.1 & 1,363 & 78.5 & 2,567 & 76.2 & 1,783 & 73.7 \\
\hline Lease & 321 & 11.8 & 170 & 9.8 & 398 & 11.8 & 299 & 12.4 \\
\hline Monthly rent & 244 & 8.9 & 113 & 6.5 & 322 & 9.6 & 177 & 7.3 \\
\hline The others & 60 & 2.2 & 90 & 5.2 & 82 & 2.4 & 160 & 6.6 \\
\hline \multicolumn{9}{|l|}{ Place of residence } \\
\hline City & 1,249 & 45.8 & 708 & 40.8 & 1,590 & 47.2 & 1,040 & 43.0 \\
\hline Town & 989 & 36.2 & 504 & 29.0 & 1,147 & 34.1 & 703 & 29.1 \\
\hline Villages & 492 & 18.0 & 524 & 30.2 & 632 & 18.8 & 676 & 28.0 \\
\hline \multicolumn{9}{|l|}{ Family type } \\
\hline Single & 69 & 2.5 & 82 & 4.7 & 198 & 5.9 & 539 & 22.3 \\
\hline Married couple & 735 & 26.9 & 1,045 & 60.2 & 1,032 & 30.6 & 701 & 29.0 \\
\hline 2 households & 1,570 & 57.5 & 354 & 20.4 & 1,721 & 51.1 & 519 & 21.5 \\
\hline 3 households & 321 & 11.8 & 203 & 11.7 & 356 & 10.6 & 562 & 23.2 \\
\hline The others & 35 & 1.3 & 52 & 3.0 & 62 & 1.8 & 98 & 4.1 \\
\hline Total & 2,730 & 100 & 1,736 & 10 & 3,369 & 100 & 2,419 & 100 \\
\hline
\end{tabular}

Missing value: 8

who are not less than 65 years old are more likely to remain single than men who are not less than 65 years old (22\% to $5 \%$ ) (Table 3 ).

\section{The Degree of PHS and ADL by Wealth and Income Level}

By and large, when other variables are not controlled, the proportion of "not good" in PHS and "have a disability" in ADL according to wealth and income level tend to decrease when the wealth and income level is high (Table 4).

In the case of the distribution according to sex and age, the proportion of "not good" in PHS is higher when it comes to those aged 65 or above (men $37 \%$, women $56 \%$ ) than when it comes to those aged under 65 (men $15 \%$, women 23\%); and the higher the quintile is, in other words, the higher the wealth and income level is, the lower the proportion of "not good" is. However, in the case of men in the 2nd quintile of the income, the proportion of not good' tends to be higher than 1st (the lowest) quintile.

In ADL, the proportion of "have a disability" was higher when the person was aged 65 or 
older (men 24\%, women 26\%) than when he or she was younger than the age of 65 (men $12 \%$, women $4 \%$ ); additionally, the higher the wealth and income level was, the lower the proportion of "have a disability" in ADL was.

\section{The Effects of Wealth and Income Level on PHS and ADL}

Tables 5 and 6 show the wealth and income level's influence on PHS and ADL controlling education, place of residence, family type, and marital status.

In the case of PHS and men aged between 45 and 64 , the OR of income level was remarkably higher than wealth level, and it was statistically significant. However, in the case of men who were not less than 65 years old, the significance of $\mathrm{OR}$ in wealth increased and the significance of $\mathrm{OR}$ in income decreased. In the case of women this tendency existed, too. It was shown that in RII this tendency also existed. By and large, the RII index according to wealth and income level appeared to be over 1 ; this fact reflects that among the lower class, more people answered 'not good' among other answers in PHS. In the end, in the case of men who were at the age of 65 or above rather than men who were under the age of 65 , RII according to wealth level tended to increase; however, RII according to income level tended to decrease. In the case of women who were at the age of 65 or above rather than the women who were under the age of 65 , relative inequality according to both wealth and income level tended to decrease. However, when it came to RII according to wealth and income level in each age group; for those under the age of 65 , relative inequality according to income level tended to be larger than relative inequality according to wealth level; however, for those aged 65 or above, RII according to wealth level tended to be larger than RII according to income level.

In the case of $\mathrm{ADL}$, it was shown that both men and women aged between 45 and 64 wealth and income level do not have a

Table 4. Self-rated health and limitation of activities of daily living (ADL) by net wealth and total income

\begin{tabular}{|c|c|c|c|c|c|c|c|c|c|c|}
\hline \multirow{3}{*}{ Sex } & \multirow{3}{*}{ Age } & \multirow{3}{*}{ Quintile } & \multicolumn{4}{|c|}{ Net asset } & \multicolumn{4}{|c|}{ Total income } \\
\hline & & & \multicolumn{2}{|c|}{ Poor ${ }^{*}$} & \multicolumn{2}{|c|}{ Disability ${ }^{\dagger}$} & \multicolumn{2}{|c|}{ Poor ${ }^{*}$} & \multicolumn{2}{|c|}{ Disability ${ }^{\dagger}$} \\
\hline & & & $\mathrm{n}$ & $\%$ & $\mathrm{n}$ & $\%$ & $\mathrm{n}$ & $\%$ & $\mathrm{n}$ & $\%$ \\
\hline \multirow[t]{12}{*}{ Male } & \multirow[t]{6}{*}{$45-64$} & 1st (lowest) & 78 & 26.7 & 35 & 12.0 & 70 & 21.7 & 40 & 12.4 \\
\hline & & 2 nd & 82 & 22.9 & 40 & 11.2 & 66 & 34.4 & 27 & 14.1 \\
\hline & & $3 \mathrm{rd}$ & 79 & 15.2 & 74 & 14.3 & 97 & 30.1 & 53 & 16.5 \\
\hline & & 4th & 93 & 12.9 & 87 & 12.0 & 115 & 13.5 & 98 & 11.5 \\
\hline & & 5th (highest) & 77 & 9.2 & 86 & 10.3 & 61 & 5.9 & 104 & 10.0 \\
\hline & & total & 409 & 15.0 & 322 & 11.8 & 409 & 15.0 & 322 & 11.8 \\
\hline & \multirow[t]{6}{*}{$\geq 65$} & 1st (lowest) & 136 & 51.9 & 98 & 37.4 & 94 & 41.6 & 62 & 27.4 \\
\hline & & $2 \mathrm{nd}$ & 133 & 47.2 & 85 & 30.1 & 189 & 45.7 & 121 & 29.2 \\
\hline & & $3 \mathrm{rd}$ & 163 & 36.3 & 84 & 18.7 & 191 & 40.0 & 121 & 25.3 \\
\hline & & 4th & 118 & 30.2 & 86 & 22.0 & 91 & 24.9 & 78 & 21.1 \\
\hline & & 5th (highest) & 86 & 24.4 & 71 & 20.2 & 71 & 28.6 & 42 & 16.9 \\
\hline & & total & 636 & 36.6 & 424 & 24.4 & 636 & 36.6 & 424 & 24.4 \\
\hline \multirow[t]{12}{*}{ Female } & \multirow[t]{6}{*}{$45-64$} & 1st (lowest) & 149 & 33.6 & 22 & 5.0 & 150 & 28.3 & 25 & 4.7 \\
\hline & & 2nd & 163 & 32.5 & 24 & 5.0 & 138 & 33.1 & 31 & 7.4 \\
\hline & & $3 \mathrm{rd}$ & 183 & 25.9 & 36 & 5.1 & 191 & 33.6 & 28 & 4.9 \\
\hline & & 4th & 165 & 20.0 & 33 & 4.0 & 199 & 22.8 & 25 & 2.9 \\
\hline & & 5th (highest) & 123 & 13.8 & 26 & 2.9 & 105 & 10.7 & 32 & 3.3 \\
\hline & & total & 783 & 23.2 & 141 & 4.2 & 783 & 23.2 & 141 & 4.2 \\
\hline & \multirow[t]{6}{*}{$\geq 65$} & 1st (lowest) & 450 & 57.8 & 301 & 38.6 & 338 & 58.9 & 189 & 32.9 \\
\hline & & $2 \mathrm{nd}$ & 347 & 65.2 & 159 & 30.0 & 521 & 58.7 & 269 & 30.3 \\
\hline & & $3 \mathrm{rd}$ & 286 & 56.4 & 82 & 16.2 & 296 & 56.9 & 113 & 21.7 \\
\hline & & 4th & 178 & 52.8 & 58 & 17.2 & 131 & 48.5 & 35 & 13.0 \\
\hline & & 5th (highest) & 98 & 37.1 & 29 & 11.0 & 73 & 43.5 & 23 & 14.0 \\
\hline & & total & 1,359 & 56.2 & 629 & 26.0 & 1,359 & 56.2 & 629 & 26.0 \\
\hline
\end{tabular}

${ }^{*}$ Self-rated health, , Limitation of ADL

significant correlation with each other. However, in the aged 65 or above group and in the case of men, the correlation of wealth level and ADL appeared statistically significant in the lowest quintile (1st quintile), and in the aged 65 or above group and in the case of women, both wealth level and income level had statistically significant influence on the low quintiles (1st and 2nd quintile). Additionally, the OR of wealth was bigger than the OR of income. In the case of RII, the OR of relative inequality according to the wealth level of men at the age of 65 or above was 2.19 (95\% CI, 1.42-3.39), and the OR of relative inequality according to the wealth level of women at the age of 65 or above was 5.04 (95\% CI, 3.327.66). This means that relative inequality according to wealth level is greater than relative inequality according to income level; especially when it comes to women, the degree of inequality is significant.

\section{DISCUSSION}

This research's significance is that it targeted seniors and the elderly to examine economic conditions that affect their health status in the aspect of income factor and wealth factor. Especially, in the aspect of health inequality research, the quintile of income and wealth status was sought to analyze how an economic gap relates to a health status gap.

The result is that income and wealth have a statistically significant correlation with the health status of seniors and the elderly. Especially, in the case of the aged (age 65 or above), the effect of wealth tends to be greater than that of income than in the case of those under the age of 65 . In other words, the relative inequality in the health status of the aged will be more apparent when the wealth variable is considered with the income variable. Moreover, the degree of relative inequality differs according to sex. In the case of men, the relative inequality in PHS between the upper class and the lower class was larger than in the case of women. On the other hand, in the case of women, the degree of RII in the aspect of $\mathrm{ADL}$ is greater than in the case of men. And also, in the case of PHS, as the subjects grew older, it came out that inequality more related to wealth than income was expanding. This 
Table 5. Effects on self-rated health and limitation of activities of daily living (ADL) - Men'

\begin{tabular}{|c|c|c|c|c|c|c|c|c|}
\hline \multirow{3}{*}{$\begin{array}{l}\text { Variable } \\
\text { Net asset }\end{array}$} & \multicolumn{4}{|c|}{ Self-rated Health ${ }^{\dagger}$} & \multicolumn{4}{|c|}{ Limitation of $\mathrm{ADL}^{\ddagger}$} \\
\hline & \multicolumn{2}{|c|}{$45-64$} & \multicolumn{2}{|c|}{$\geq 65$} & \multicolumn{2}{|c|}{$45-64$} & \multicolumn{2}{|c|}{$\geq 65$} \\
\hline & OR & $95 \% \mathrm{CI}$ & OR & $95 \% \mathrm{CI}$ & OR & $95 \% \mathrm{CI}$ & OR & $95 \% \mathrm{CI}$ \\
\hline 5th (highest) & 1.00 & & 1.00 & & 1.00 & & 1.00 & \\
\hline 4th & 1.08 & $0.77-1.51$ & 1.19 & $0.85-1.67$ & 1.15 & $0.83-1.59$ & 1.02 & $0.71-1.47$ \\
\hline $3 \mathrm{rd}$ & 1.03 & $0.72-1.49$ & 1.31 & $0.93-1.82$ & 1.33 & 0.94-1.89 & 0.75 & $0.52-1.10$ \\
\hline 2nd & 1.43 & $0.98-2.10$ & 2.02 & $1.41-2.90$ & 0.95 & $0.62-1.45$ & 1.45 & $0.98-2.14$ \\
\hline 1st (lowest) & 1.55 & $1.04-2.31$ & 2.56 & $1.77-3.71$ & 0.92 & $0.59-1.46$ & 1.88 & $1.27-2.78$ \\
\hline RII & 1.64 & $1.07-2.54$ & 3.19 & $2.14-4.74$ & 1.00 & $0.64-1.58$ & 2.19 & $1.42-3.39$ \\
\hline Total income & OR & $95 \% \mathrm{CI}$ & OR & $95 \% \mathrm{CI}$ & OR & $95 \% \mathrm{CI}$ & OR & $95 \% \mathrm{CI}$ \\
\hline 5th (highest) & 1.00 & & 1.00 & & 1.00 & & 1.00 & \\
\hline 4th & 1.80 & $1.28-2.53$ & 0.80 & $0.55-1.16$ & 1.12 & $0.82-1.52$ & 1.31 & $0.86-2.01$ \\
\hline $3 \mathrm{rd}$ & 4.02 & $2.75-5.88$ & 1.42 & $1.00-2.01$ & 1.65 & $1.12-2.44$ & 1.57 & $1.04-2.35$ \\
\hline 2nd & 5.15 & $3.38-7.84$ & 1.74 & $1.22-2.50$ & 1.36 & $0.84-2.19$ & 1.67 & $1.10-2.54$ \\
\hline 1st (lowest) & 2.93 & $1.97-4.36$ & 1.57 & $1.04-2.37$ & 1.15 & $0.76-1.73$ & 1.48 & $0.93-2.37$ \\
\hline RII & 5.86 & $3.85-8.93$ & 2.36 & $1.57-3.54$ & 1.50 & $0.95-2.34$ & 1.59 & $1.02-2.48$ \\
\hline
\end{tabular}

RII: relative index of inequality

Adjusted for family type, marital status, education level and place of residence

+ Poor $=1$, No poor $=0$, $*$ Disability $=1$, No disability $=0$

Table 6. Effects on self-rated health and limitation of activities of daily living (ADL)-Women

\begin{tabular}{|c|c|c|c|c|c|c|c|c|}
\hline \multirow{3}{*}{$\begin{array}{l}\text { Variable } \\
\text { Net asset }\end{array}$} & \multicolumn{4}{|c|}{ Self-rated Health ${ }^{\dagger}$} & \multicolumn{4}{|c|}{ Limitation of $\mathrm{ADL}^{\ddagger}$} \\
\hline & \multicolumn{2}{|c|}{$45-64$} & \multicolumn{2}{|c|}{$\geq 65$} & \multicolumn{2}{|c|}{$45-64$} & \multicolumn{2}{|c|}{$\geq 65$} \\
\hline & OR & $95 \% \mathrm{CI}$ & OR & $95 \% \mathrm{CI}$ & OR & $95 \% \mathrm{CI}$ & OR & $95 \% \mathrm{CI}$ \\
\hline 5th (highest) & 1.00 & & 1.00 & & 1.00 & & 1.00 & \\
\hline 4th & 1.13 & $0.86-1.48$ & 1.62 & $1.15-2.27$ & 1.20 & $0.70-2.05$ & 1.41 & $0.87-2.31$ \\
\hline $3 \mathrm{rd}$ & 1.23 & $0.93-1.62$ & 1.67 & $1.21-2.31$ & 1.29 & $0.75-2.23$ & 1.11 & $0.69-1.78$ \\
\hline $2 \mathrm{nd}$ & 1.71 & $1.28-2.30$ & 2.44 & $1.75-3.40$ & 1.15 & $0.63-2.11$ & 2.33 & $1.48-3.67$ \\
\hline 1st (lowest) & 1.84 & $1.36-2.49$ & 1.91 & $1.38-2.65$ & 1.17 & $0.63-2.17$ & 3.16 & $2.02-4.93$ \\
\hline RII & 2.19 & $1.57-3.04$ & 1.84 & $1.30-2.62$ & 1.17 & $0.60-2.27$ & 5.04 & $3.32-7.66$ \\
\hline Total income & OR & $95 \% \mathrm{CI}$ & OR & $95 \% \mathrm{CI}$ & OR & $95 \% \mathrm{CI}$ & OR & $95 \% \mathrm{CI}$ \\
\hline 5th (highest) & 1.00 & & 1.00 & & 1.00 & & 1.00 & \\
\hline 4th & 1.68 & $1.28-2.21$ & 1.13 & $0.76-1.69$ & 0.70 & $0.40-1.21$ & 0.89 & $0.50-1.58$ \\
\hline $3 \mathrm{rd}$ & 2.18 & $1.62-2.92$ & 1.31 & $0.90-1.91$ & 1.02 & $0.58-1.79$ & 1.44 & $0.86-2.40$ \\
\hline 2nd & 2.21 & $1.60-3.03$ & 1.41 & $0.98-2.05$ & 1.69 & $0.96-2.98$ & 1.71 & $1.03-2.82$ \\
\hline 1st (lowest) & 2.21 & $1.62-3.00$ & 1.54 & $1.04-2.28$ & 1.22 & $0.68-2.19$ & 1.70 & $1.01-2.86$ \\
\hline RII & 2.56 & $1.82-3.59$ & 1.50 & $1.04-2.15$ & 1.90 & $0.96-3.77$ & 1.73 & $1.13-2.63$ \\
\hline
\end{tabular}

RII: relative index of inequality

"Adjusted for family type, marital status, education level and place of residence

+ Poor $=1$, No poor $=0$, ${ }^{\circ}$ Disability $=1$, No disability $=0$

result was more remarkable in the case of men than women. This phenomenon comes from the fact that wealth or income level cannot reflect the SEP of women (because of the discrepancy of wealth between a husband and wife) or the intervention of the effect of other variables, like education. Thus, with the stratification of other SEP indicators, it is requested that post researches check the tendency of how and with what each index's effect is replaced in the process of aging. Moreover, in the case of ADL in the group of those aged 65 or above, the influence of wealth and income appears, and the inequality according to wealth level is larger than the
SEP indexes. According to a recent domestic research which used RII to compare the relationship between income level and PHS, after financial crisis (1997) deepening economic inequality resulted severe gap of health status: forties and fifties had shown the most severe gap and then getting older shown decreasing inequality [31]. The authors supposed that this result was caused by survivor selection bias. However, the assertion that if income and wealth variable had been put into the research these inequality would remain is more proper than the assertion that decease caused low inequality.

Furthermore, for wealth to be elaborately used as SEP index, consented standard for the composition of wealth will be necessary. In this research Smith and Goldman's standard [32], in which SEP is independent variable and health is dependent variable, was revised and adopted. In many domestic and foreign documents there are various measuring methods of wealth level: one is asking the number and possession of specific good $[18,33]$, another is asking both income and wealth in the form of self-report like PHS [34] and the other is adding up wealth, income and debt to decide quintile [35]. According to domestic researches on the composition of household income and wealth, total income and net wealth, which are the results of a method presented in Tables 1 and 2, were used as analyzing tools [22-26]; thus, this research also adopted this method. In that wealth, according to age, has a close relationship with income, on the one hand, wealth is the accumulation of income; however, it can greatly vary according to inheritance and donation, and grasping a household's total among of assets rather than calculating personal economic action is more important [17]. And a proxy index, like immovable property or FAS, should be positively reflected and measured in the aspect of a life course to devise a wealth measuring utility to reflect personal market power stably and in the long 
term regardless of changes in society. Comparing the effect of wealth and income as a separate SEP index is a long-term subject of analysis [36,37].

This research analyzed health inequality using conjugal income and wealth of seniors and the elderly. Generally, indicators usually used in researches are the values which is adjusted by the number of family members. Both household income and conjugal income premise that income will be distributed to all family members equally. However, with the judgment that conjugal income is more apt than household income to represent the income of seniors and the elderly, conjugal income was adopted to figure out the income of seniors and the elderly. However, taking a patriarchal family type into consideration, it is possible that income and wealth are not equal to both sexes, so the results regarding the cases of women could have been underestimated. And with the value of conjugal income and wealth as the central feature, quintiles were yielded and applied to the target of research; thus, it is possible that in the case of the group with a low income/low wealth whose members (a family of widower or widow) are not all existent, the result could have been overestimated. Nevertheless, considering the condition of the data and the parsimony of current analysis on the current domestic seniors and the elderly who are able to work, the above method will be reasonable.

This research examined the relation one's wealth and income have with health status in seniors and the elderly using the standard of the age of 65 [under the age of $65(<65)$ or not less than the age of $65(\geq 65)$ ] using KLoSA 1st year data. The result indicates that, in the case of the elderly, the wealth effect is bigger than the income effect and the degree of health inequality was higher than in the senior group, who are more likely to be affected by income. Thus, when conducting researches on the health equity of the elderly, it is necessary to consider the wealth variable, which has been neglected compared to the income variable. It has been shown that this wealth effect varies depending on sex; therefore, this fact should receive careful examination continuously.

\section{REFERENCES}

1.Link BG, Phelan J. Social conditions as fundamental causes of disease. J Health Soc Behav 1995; (Spec No): 80-94.

2. Marmot M. The Status Syndrome: How Social Standing Affects Our Health and Longevity. London: Holt Paperbacks; 2005. p. 61-81.

3.Lynch JW, Kaplan GA. Socioeconomic position. In: Berkman LF, Kawachi I, editors. Social Epidemiology. New York: Oxford University Press; 2000. p. 13-35.

4. Siegrist J, Marmot M, editors. Social Inequalities in Health: New Evidence and Policy Implications. New York: Oxford University Press; 2006.p.73-100.

5. Choi YJ, Jeong BG, Cho SI, Jung-Choi K, Jang $\mathrm{SN}$, Kang M, et al. A review on socioeconomic position indicators in health inequality research. J Prev Med Public Health 2007; 40(6): 475-486. (Korean)

6.House JS. Understanding social factors and inequalities in health: 20th century progress and 21st prospects. J Health Soc Behav 2002; 43(2): 125-142.

7. Macintyre S, McKay L, Der G, Hiscock R. Socio-economic position and health: What you observe depends on how you measure it. $J$ Public Health Med 2003; 25(4): 288-294.

8. Geyer S, Hemstrom O, Peter R, Vagero D. Education, income, and occupational class cannot be used interchangeably in social epidemiology: Empirical evidence against a common practice. J Epidemiol Community Health 2006; 60(9): 804-810.

9. Khang YH, Kim HR. Explaining socioeconomic inequality in mortality among South Koreans: An examination of multiple pathways in a nationally representative longitudinal study. Int J Epidemiol 2005; 34(3): 630-637.

10. Galobardes B, Shaw M, Lawlor DA, Lynch JW, Davey Smith G. Indicators of socioeconomic position (part 1). J Epidemiol Community Health 2006; 60(1): 7-12.

11. Galobardes B, Shaw M, Lawlor DA, Lynch JW, Davey Smith G. Indicators of socioeconomic position (part 2). J Epidemiol Community Health 2006; 60(2): 95-101.

12.Duncan GJ, Daly MC, McDonough P, Williams DR. Optimal indicators of socioeconomic status for health research. Am J Public Health 2002; 92(7): 1151-1157.
13. Krieger N, Chen JT, Selby JV. Comparing individual-based and household-based measures of social class to assess class inequalities in women's health: A methodological study of 684 U.S. women.J Epidemiol Community Health 1999; 53(10): 612-623.

14. Muntaner C, Eaton WW, Diala C, Kessler RC, Sorlie PD. Social class, assets, organizational control and the prevalence of common groups of psychiatric disorders. Soc Sci Med 1998; 47(12): 2043-2053.

15.Lee SG, Jeon SY. The relations of socioeconomic status to health status, health behaviors in the elderly. J Prev Med Public Health 2005; 38(2); 154-162. (Korean)

16. Lee HY, Kim SA, Lee HJ, Jung SH. The relationship between socio-economic factors and self-rated health among older people. Korean J Health Policy Admin 2005; 15(2): 70-83. (Korean)

17.Jung MS. Applications of socio-economic position indicators in health inequality studies: Research trends and implications. Korean J Public Health 2007; 44(2): 133-154. (Korean)

18.Zimmer Z. Poverty, wealth inequality and health among older adults in rural Cambodia. Soc Sci Med 2008; 66(1): 57-71.

19. Robert S, House JS. SES differentials in health by age and alternate indicators of SES. J Aging Health 1996; 8(3): 359-388.

20. Braveman PA, Cubbin C, Egerter S, Chideya S, Marchi K, Metzler M, et al. Socioeconomic status in health research: One size does not fit all. JAMA 2005; 294(22): 2879-2887.

21.Zimmer Z, Kwong J. Socioeconomic status and health among older adults in rural and urban China. J Aging Health 2004; 16(1): 4470.

22. Ban JH. Analysis on the structure of asset inequality among the middle-aged and elderly households. Mon Labor Rev 2008; (4): 4-22. (Korean)

23. Bae MK, Hong GS. A study of asset portfolio and impact variables affecting on the aged. Korean J Hum Ecol 2006; 15(6): 973-984. (Korean)

24. Moon SJ, Joung SH, Yuh YK. Determinants of household's net worth level. J Consum Stud 2002; 13(3): 169-188. (Korean)

25. Kim YJ. The comparative analysis of income, expenditure and asset between retired elderly households and employed elderly households. J Korean Home Econ Assoc 1998; 36(7): 5767. (Korean)

26. Nam SH, Kwon S. Asset distribution, inequality, and poverty among elderly households in Korea. Health Soc Welf Rev 2008; 28(2): 3-32. (Korean) 
27. Jeon SH, Lim BI. An analysis on changes of household asset and debt between 2000 and 2006. Korean J Public Finance 2008; 1(2): 133-162. (Korean)

28. The Korean Society for Equity in Health. Methods in Health Inequalities Measurement. Seoul: Hanul Publishing Group; 2007. (Korean)

29. Sergeant JC, Firth D. Relative index of inequality: Definition, estimation and inference. Biostatistics 2005; 7(2): 213-224.

30. Hayes LJ, Berry G. Sampling variability of the Kunst-Mackenbach relative index of inequality. J Epidemiol Community Health 2002; 56(10): 762-765.
31. Jung Y, Cho YT, Oh JH. Differential effects of family income on self-rated health by age: Analysis of Seoul Citizens Health Indicators Survey 2001, 2005. J Prev Med Public Health 2007; 40(5): 381-387.(Korean)

32. Smith KV, Goldman N. Socioeconomic differences in health among older adults in Mexico. Soc Sci Med 2007; 65(7): 1372-1385.

33. Keddie AM, Peek MK, Markides KS. Variation in the associations of education, occupation, income, and assets with functional limitations in older Mexican Americans. Ann Epidemiol 2005; 15(8): 579-589.

34. Costa-Font J. Housing assets and the socioeconomic determinants of health and disability in old age. Health Place 2008; 14(3): 478-491. 35. Montgomery SM, Netuveli G, Hildon Z, Blane D. Does financial disadvantage at older ages eliminate the potential for better health? $J$ Epidemiol Community Health 2007; 61(10): 891-895.

36. Krieger N, Williams DR, Moss NE. Measuring social class in US public health research: Concepts, methodologies, and guidelines. Annu Rev Public Health 1997; 18: 341-378.

37. Lynch JW, Kaplan GA, Shema SJ. Cumulative impact of sustained economic hardship on physical, cognitive, psychological, and social functioning. N Engl J Med 1997; 337(26): 1889-1895. 